\title{
A CATALOGUE OF BATS RECORDED IN THRISSUR DISTRICT, KERALA
}

\author{
A. Madhavan
}

Kailath Tharavadu, Paralam, Thrissur, Kerala 680575, India.

\begin{abstract}
An extensive survey and collection of specimens of 24 taxa of bats representing six families and 14 genera (barring Rhinopomatidae) were made in Thrissur District, Kerala during the years between 1990 and 1999; a few places in the northern and other central and southern districts of Kerala also were explored. All these places are agricultural areas. In the majority of cases specimens of different species of bats were collected from their roosts during day time. Total number of specimens of different species of bats collected ranges from a minimum of two to a maximum of about 550 .
\end{abstract}

\section{Keywords}

Bats, inventory, Thrissur District, Kerala

\begin{abstract}
Introduction
A faunistic survey by Blanford (1891) and some observations on the breeding biology of Asiatic Greater Yellow House Bat (Scotophilus heathii) (Ramakrishna \& Madhavan, 1977; Gopalakrishna \& Madhavan, 1978; Madhavan, 1981; Sastry \& Madhavan, 1984, 1986) and studies on the taxonomy and geographical distribution of six species of bats obtained by the 1980 Silent Valley Expedition (Das, 1986) are the only studies on bats of Kerala. A detailed survey of bats of Kerala undertaken by the author embodies observations on some aspects of ecology, behaviour and reproduction of bats.
\end{abstract}

\section{Materials and Methods}

Geographical areas covered by the present study (Fig. 1 and 2) include several villages in Thrissur District. A few places in the districts of Kozhikode, Ernakulam, Kottayam, Alappuzha and Kollam also have been explored. All these places are agriculture oriented. Total number of specimens of different species of bats collected during the period between 1900 and 1999 ranges from a minimum of two to about a maximum of 550 specimens, the lowest being those of Myotis and Tadarida species, and the highest being that of Tylonycteris pachypus. The specimens of

Received 19 June 2000 Accepted 25 September 2000 bats were collected from their roosts during the day except those which were netted from trees, or caught during their flight in the evening or under other special cirumstances. The specimens were collected from ridges and clefts in the wall of wells, under the roofs and between tiles of roofs of houses, hollows in tree trunks, within the whorls of leaves of plantain, the grass reeds and holes underneath these, the internodal cavities of bamboo, the lofts of houses, subterranean refuges, etc. Long forceps, butterfly nets, fishing nets and Japanese mist nets were used to catch the specimens. The body weights, forearm length, fur colour, nature of mammary glands and external genitalia of females and the nature of the scrotum and the penis in the males were recorded. Several specimens of different taxa of bats under critical reproductive stages were dissected for their different genital organs and other parts, and these were fixed in appropriate fixatives and preserved. In some cases, specimens were maintained in captivity for the purpose of observing their breeding behaviour and also for conducting experiments under restricted conditions. Rest of the specimens were set free. The specimens were identified by the British Museum, London and by the Zoological Survey of India, Calcutta. Representative specimens of each species of bats collected have been deposited in these Institutes.

\section{Results and Discussions}

Out of the 18 families of living bats (Hill \& Smith, 1988) eight families are represented in India. This survey in Kerala has been able to enlist 24 bat species representing six families and 14 genera leaving those from Rhinopomatidae whose distribution is associated with xerothermic conditions (Brosset, 1962). However, Rhinopoma hardwickii has been recorded from the humid coastal and other areas (Bhat \& Sreenivasan, 1972, 1990). Further survey may be helpful to locate members of this family farther south in India. Most of the specimens were collected from their roosts except Rousettus leschenaulti, Hipposideros fulvus and Tadarida aegyptiaca. R. leschenaulti was netted from guava trees; $H$. fulvus was caught during their flight, and $T$. aegyptiaca was caught once during its flight and on another occasion when it had blundered into a room. Myotis horsfieldii and Myotis montivagus peytoni appears to be rare in this region. Other species such as Taphozous saccolaimus, Rhinolophus beddomei and Kerivoula picta are not as rare as believed, but 
Figure 1. Map of Kerala showing collection locations

1. Thrissur

2. Cherpur

3. Ollur

4. Pazhayannur

5. Kodungallur

6. Mathilakam

7. Vellangallur

8. Paralam

9. Pallippuram

10. Kodannur

11. Venginissery

12. Chenam

13. Kandassamkadavu

14. Alappad

15. Kottekkadu

16. Palissery

17. Talikulam

18. Chirakkal

19. Urakam

20. Thaniyam

21. Venkitangu

22. Mannuthy
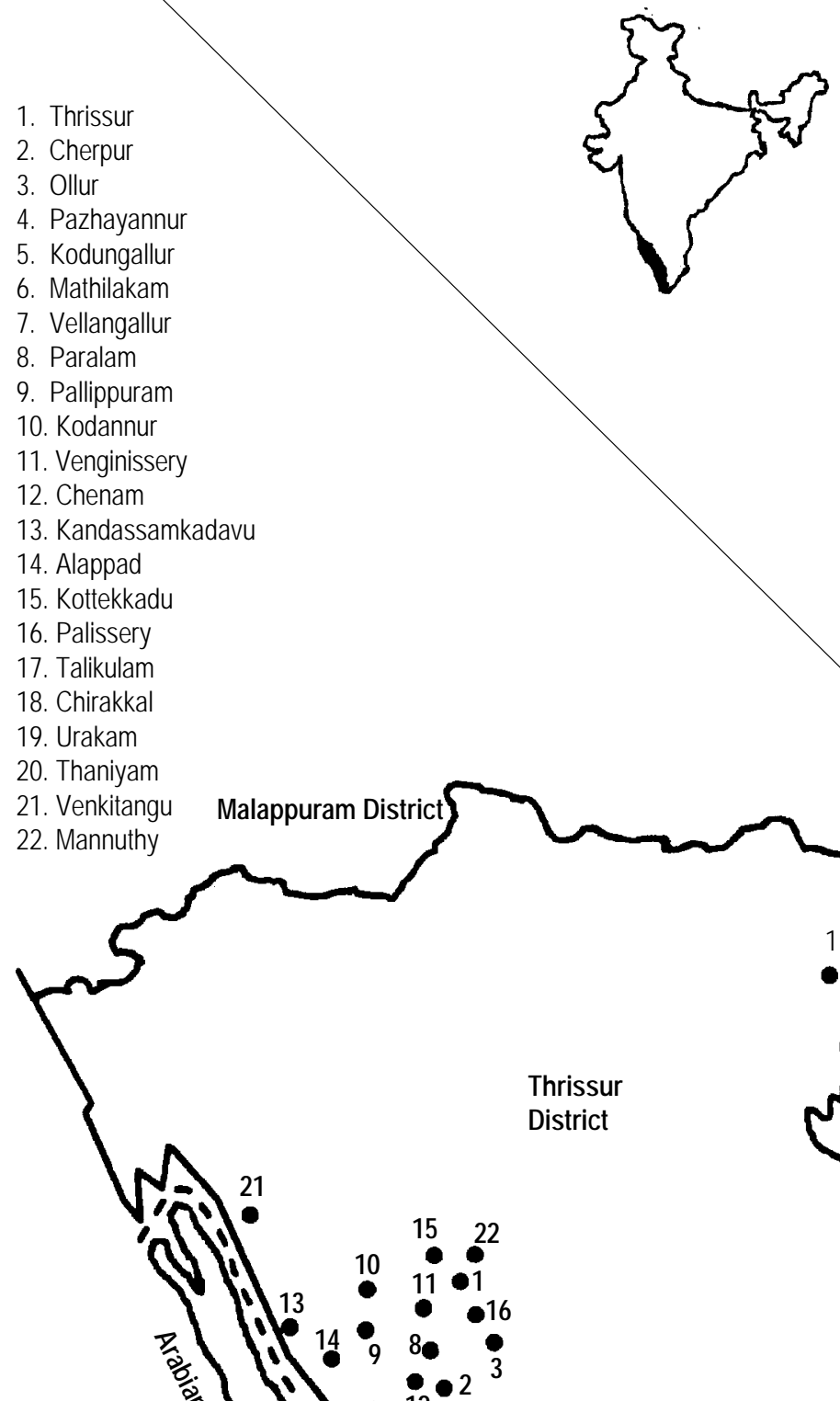

Thrissur

District
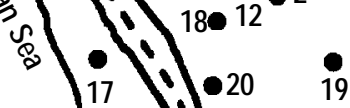

Thiruvanthapuram

2. Kollam

3. Alappuzha

4. Kottayam

5. Ernakulam

6. Thrissur

7. Kozhikode
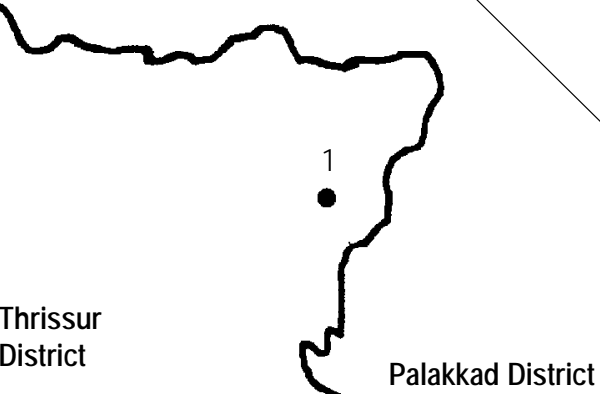

串

Karnataka
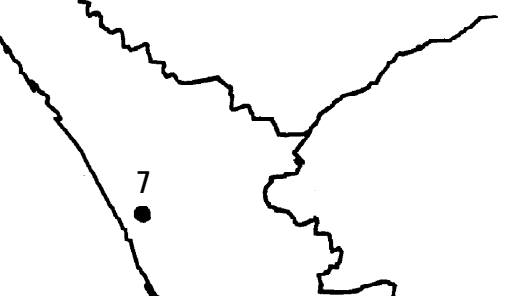

3
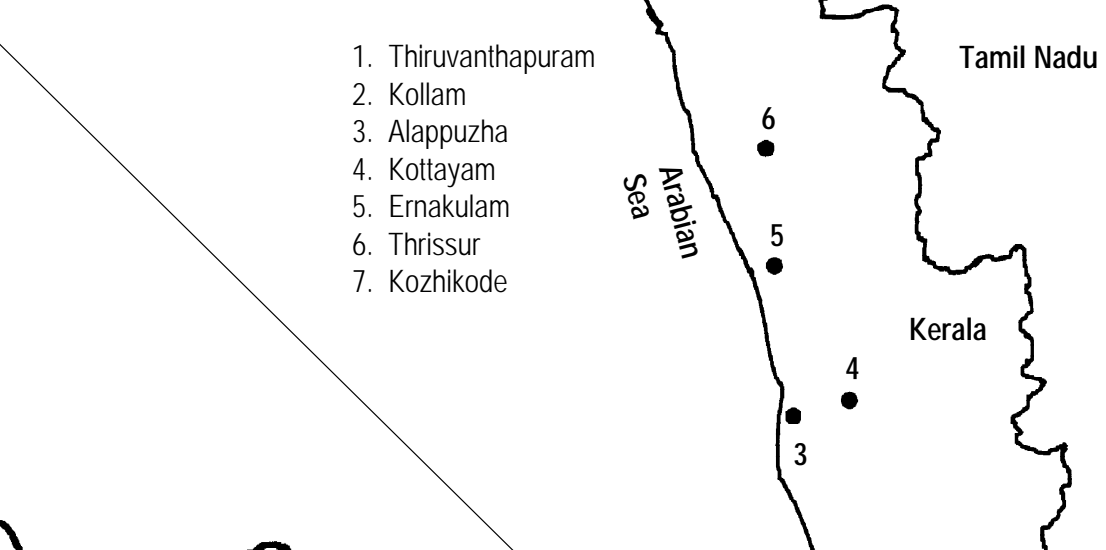

\{

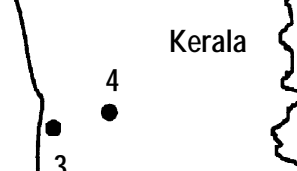


Table 1. Bats (Order: Chiroptera) recorded in Kerala with special reference to Thrissur District.

\section{Common and Scientific Name}

Suborder: Megachiropetera

Family: Pteropodidae

Flying Fox

Pteropus giganteus (Brunnich, 1782)

Indian Fulvus Fruit Bat

Rousettus leschenaulti (Desmarest, 1820)

Short-nosed Fruit Bat

Cynopterus sphinx (Vahl, 1797)

\section{Suborder: Microchiroptera}

Family: Emballonuridae

Pouch-bearing Bat

Taphozous saccolaimus Temminck, 1838

Black-bearded Tomb Bat

Taphozous melanopogon (Temminck, 1841)

Long-winged Tomb Bat

Taphozous longimanus Hardwicke, 1825

Family: Megadermatidae

Indian False Vampire (Greater False Vampire Bat)

Megaderma lyra E.Geoffroy, 1810

Malaya False Vampire (Lesser False Vampire Bat) Megaderma spasma horsfieldi (Blyth, 1863)

Family: Rhinolophidae

Rufous Horse-shoe Bat

Rhinolophus rouxii rouxii (Temminck, 1835)

Little Indian Horse-shoe Bat

Rhinolophus lepidus Blyth, 1844

Lesser Wooly Horse-shoe Bat

Rhinolophus beddomei (Anderson, 1905)

Family: Hipposideridae

Dusky Leaf-nosed Bat

Hipposideros ater ater (Templeton, 1848)

Andersen's Leaf-nosed Bat

Hipposideros pomona pomona (Andersen, 1918)

Schneider's Leaf-nosed Bat

Hipposideros speoris (Schneider, 1800)

Fulvous leaf-nosed Bat

Hipposideros fulvus (Gray, 1838)

Family: Vespertilionidae

Least Pipistrelle

Pipistrellus tenuis (Wroughton, 1899)

Kelaart's Pipistrelle

Pipistrellus ceylonicus (Kelaart, 1852)

Collected From Localities

Large trees.

Guava tree. Netted at night.

Hanging fronds of palm trees. Sometimes old houses and hollows of trees.

Mainly from hollows of decayed trunks of jaggery palm; occasionally houses.

Underneath the tiles in the roof of a church. Ernakulam

Underneath a road bridge

Ernakulam

Lofts of old houses

Lofts of old houses. Among leaves of coconut tree

Irrigation water tunnel.

Hollows in the walls of wells.

Subterraneous refuge.

Hollows in the walls of wells.

Rarely also from houses.

Dark, cool dungeons; hollows in the walls of wells; car porches; among the grass, reeds and holes undernath these.

Car porch; Parapet enclosures of houses.

Underground cellars: under bridges; caves; Kozhikode, Ernakulam uninhabited old palaces.

Netted while fluttering in the evening.

Crevices in the walls and door frames; under the tiles of roof of houses; hollows of coconut tree trunk; spathes of coconut tree.

Hollows in the coconut tree trunk
Villages as well as most cities.

Ernakulam

Thrissur (Cherpu, Paralam, Kodanur, Venginissery, Chenam, Chirakkal)

Thrissur (Venlangallur, Pallipuram, Paralam)
Thrissur (Mathilakom, Paralam, Venginissery, Chenam, Thalikkulam, Urakam), Ernakulam

Thrissur (Paralam, Venginissery)

Thrissur (Kottekkadu), Ernakulam

Kozhikode, Kollam

Thrissur (Paralam, Pallipuram, Venginissery, Kottekadu)

Thrissur (Pazhayannur, Kodungallur Mathilakom, Paralam, Pallipuram, Chenam, Alapad), Kozhikode, Ernakulam, Alapuzha

Thrissur (Venginissery), Alapuzha

Ernakulam

Thrissur (Paralam, Pallipuram, Venginissery, Chirakkal), Ernakulam

Thrissur (Paralam, Pallipuram, Kodanur, Venginissery, Chenam, Chirakkal, Taniyam) 


\begin{tabular}{|c|c|c|}
\hline Common and Scientific Name & Collected From & Localities \\
\hline $\begin{array}{l}\text { Dormer's Bat } \\
\text { Pipistrellus dormeri (Dobson, 1875) }\end{array}$ & $\begin{array}{l}\text { Hollows in the coconut tree trunk; } \\
\text { under the tiles on roof of houses; } \\
\text { under road bridges. }\end{array}$ & $\begin{array}{l}\text { Thrissur (Paralam, Pallipuram, Venginissery, } \\
\text { Chenam) }\end{array}$ \\
\hline $\begin{array}{l}\text { Asiatic Greater Yellow House Bat } \\
\text { Scotophilus heathii Horsfield, } 1831\end{array}$ & Under tiles of roof of houses. & $\begin{array}{l}\text { Thrissur (Paralam, Ollur, Pallipuram, } \\
\text { Venginissery, Chenam, Kandassankadavu, } \\
\text { Palisseri, Venkitangu) }\end{array}$ \\
\hline $\begin{array}{l}\text { Indian Painted Bat. } \\
\text { Kerivoula picta picta (Hill, 1965) }\end{array}$ & $\begin{array}{l}\text { Inside rolled-up dry or tender leaves of } \\
\text { plantain tree. Netted in the house. }\end{array}$ & $\begin{array}{l}\text { Thrissur (Paralam, Pallipuram, Venginissery), } \\
\text { Kottayam. }\end{array}$ \\
\hline $\begin{array}{l}\text { Bamboo Bat. } \\
\text { Tylonycteris pachypus (Temminck, 1840) }\end{array}$ & Inside the internodal cavities of bamboo. & $\begin{array}{l}\text { Thrissur (Cherpu, Ollur, Paralam, Pallipuram, } \\
\text { Kodanur, Venginissery, Urakam, Taniyam, } \\
\text { Mannuthy) }\end{array}$ \\
\hline $\begin{array}{l}\text { Horsfield's Bat } \\
\text { Myotis horsfieldii (Temminck, 1840) }\end{array}$ & $\begin{array}{l}\text { Cavity in the wall of well. Subterranean } \\
\text { refuge. }\end{array}$ & Kozhikode \\
\hline $\begin{array}{l}\text { Burmese Whiskered Bat } \\
\text { Myotis montivagus peytoni (Wroughton \& Ryley, 1913) }\end{array}$ & Subterranean refuge. & Kozhikode \\
\hline $\begin{array}{l}\text { Egyptian Free-tailed Bat } \\
\text { Tadarida aegyptiaca thomasi (Wroughton, 1919) }\end{array}$ & $\begin{array}{l}\text { Caught accidentally while being chased by } \\
\text { a crow; another specimen blundered into a } \\
\text { room and hid itself inside a hung shirt. }\end{array}$ & Thrissur (Venginissery), Ernakulam \\
\hline
\end{tabular}

Taxonomy and nomenclature after Bates and Harrison, 1997.

only difficult to track down.

Kerala isan El Dorado of bats. This is a land of monsoon, and the climate does not suffer wide fluctuations and intolerable extremes. Fruits and insects are in abundance in such situations.

\section{Acknowledgements}

The author expresses his gratitude to Prof. A. Gopalakrishna for initiating him into bat study. This research project was supported by the State Committee on Science, Technology and Environment, Govt. of Kerala, and by University Grants Commission, New Delhi. Author thanks the late Dr. John E. Hill (British Museum) and Dr. P.K. Das, Zoological Survey of India, Calcutta, for taking pains to identify the specimens.

\section{References}

Bates, P.J.J. and D.L. Harrison (1997). Bats of the Indian Subcontinent. Harrison Zoological Museum, Kent. xvi +258 pp.

Bhat, H.R. and M.A. Sreenivasan (1972). Occurance of Rhinopoma hardwickei, Gray, 1831, the lesser rat-tailed bat in a humid area of coastal Mysore. J. Bombay nat. Hist. Soc., 69(1): 172.

Bhat, H.R. and M.A. Sreenivasan (1990). Records of bats in Kyasanur Forest disease area and environs in Karnataka State, India, with ecological notes. Mammalia 54(1): 69-106.

Blanford, W.T. (1988-1891). The Fauna of British India - Mammalia, London.

Brosset, A. (1962). The bats of Central and Western India, Part 1. J. Bombay nat. Hist. Soc., 59(1): 1-57.

Das, P.K. (1986). Studies on the taxonomy and geographical distribution of the species of bats obtained by the Silent Valley (Kerala, India) expedition, 1980. Rec. Zool. Survey, 84(1-4): 259-276.

Gopalakrishna, A. and A. Madhavan (1978). Viability of spermatozoa in the Indian Vespertilionid bat, Scotophilus heathi (Horsfield). Indian J. Exp. Biol. 16(7): 852-854.

Hill, J.E. and J.D. Smith (1988). Bats - A Natural History. British Museum (Natural History), London.

Madhavan, A. (1981). Breeding habits and associated phenomenon in some Indian bats, Part VI - Scotophilus heathi (Horsfield) Vespertilionidae. J. Bombay nat. Hist. Soc. 77(2): 227-237.

Ramakrishna, P.A. and A. Madhavan (1977). Foetal membranes and placentation in the Vespertilionid bat, Scotophilus heathi (Horsfield). Proc. Indian Acad. Sci. 86B(2): 117-126.

Sastry, M.S. and A. Madhavan (1984). Early development, inplantation and amniogenesis in the Microchiropteran bat, Scotophilus heathi (Horsfield). Proc. Nat. Acad. Sci. India 54B(1): 9-20.

Sastry, M.S. and A. Madhavan (1986). Development of foetal membranes and placentation in a Microchiropteran bat, Scotophilus heathi (Horsfield). Proc. Nat. Acad. Sci. India 56B(3): 187-198. 